Article

\title{
Effect of Four Pollinating Sources on Nutritional Properties of Medjool Date (Phoenix dactylifera L.) Seeds
}

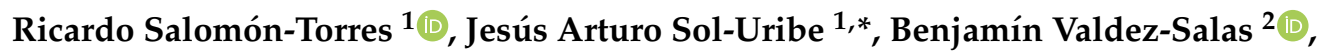 \\ Conrado García-González ${ }^{3, * i D}$, Robert Krueger ${ }^{4}$, Daniel Hernández-Balbuena ${ }^{5}$, \\ Susana Norzagaray-Plasencia ${ }^{5}$, Juan Pablo García-Vázquez ${ }^{5}$ (D) and Noé Ortiz-Uribe ${ }^{1}$ \\ 1 Departamento de Posgrado, Universidad Estatal de Sonora, San Luis Rio Colorado, Sonora 83500, Mexico; \\ ricardo.salomon@uabc.edu.mx (R.S.-T.); sinhuet7@hotmail.com (N.O.-U.) \\ 2 Laboratorio de Materiales Avanzados, Universidad Autónoma de Baja California, Mexicali, \\ Baja California 21100, Mexico; benval@uabc.edu.mx \\ 3 Laboratorio de Procesos Industriales, Universidad Autónoma de Baja, California Mexicali, \\ Baja California 21100, Mexico \\ 4 USDA-ARS National Clonal Germplasm Repository for Citrus and Dates, Riverside, CA 92507, USA; \\ robert.krueger@ars.usda.gov \\ 5 Facultad de Ingeniería, Universidad Autónoma de Baja California, Mexicali, Baja California 21100, Mexico; \\ dhernan@uabc.edu.mx (D.H.-B.); susana.norzagaray.plasencia@uabc.edu.mx (S.N.-P.); \\ pablo.garcia@uabc.edu.mx (J.P.G.-V.) \\ * $\quad$ Correspondence: jsoluribe@yahoo.com.mx (J.A.S.-U.); cnrdgarciag@uabc.edu.mx (C.G.-G.); \\ Tel.: +52-653-534-4255 (J.A.S.-U.); +52-686-566-4150 (C.G.-G.)
}

Received: 7 January 2020; Accepted: 14 February 2020; Published: 18 February 2020

\begin{abstract}
The objective of this study was to evaluate the effect of pollen source on the nutritional composition of seeds of the 'Medjool' date (Phoenix dactylifera L.) under conditions of northwest Mexico. The content of nutrients (protein, lipids, fiber, and ash), sugars (total, reducing, and non-reducing), and most abundant minerals, were evaluated, as well as antioxidant activities. The pollen of four cultivars ('Deglet Noor', 'Khadrawy', 'Medjool', and 'Zahidi') was selected. Four groups of three bunches were pollinated in each of the female palms. For the four treatments, the following ranges were obtained: Seeds had a weight of 1.32-1.41 g and low concentrations of protein (4.44-5.49 g/100 g) and lipids (9.62-10.19 g/100 g). The content of dietary fiber and ash was 59.65-72.59 g/100 g and $1.09-1.42 \mathrm{~g} / 100 \mathrm{~g}$, respectively. Total sugars content was 4.50-6.96 g/100 g, while the insoluble solids were $92.21-96.03 \mathrm{~g} / 100 \mathrm{~g}$. The predominant mineral was potassium with $399.97-459.79 \mathrm{mg} / 100 \mathrm{~g}$ dry weight, followed by sulfur with $135.51-162.67 \mathrm{mg} / 100 \mathrm{~g}$ dry weight. Finally, for antioxidant activities, DPPH (2,2'-diphenyl-1-picrylhydrazyl) and ABTS (2,2'-azino-bis(3-ethylbenzothiazoline-6-sulfonic acid)) assay results were $0.0014-0.0094 \mathrm{IC}_{50} \mathrm{~g} / \mathrm{L}$ and $0.176-0.299 \mathrm{IC}_{50} \mathrm{~g} / \mathrm{L}$, respectively. The pollen sources had an effect on the physicochemical properties of the seeds of the 'Medjool' cultivar date. However, some of the parameters (diameter, total acidity, $\mathrm{pH}$ ) did not show statistically significant differences. The pollen sources from the 'Khadrawy' and 'Medjool' cultivars were the ones that induced differences in physical, proximate, and nutritional parameters, while pollen from the 'Zahidi' source induced the largest differences for minerals. The results suggest that selection of the source of pollen has a significant effect on the nutritional properties of the date seed from the cultivar 'Medjool', and that its use could be feasible as a functional food or by-product of the date production.
\end{abstract}

Keywords: date palm; Phoenix dactylifera L.; medjool; date seed; pollination 


\section{Introduction}

The fruit of the date palm (Phoenix dactylifera L.) is commercially cultivated in the arid and semi-arid regions of the world, playing an important role in the economic aspects of countries in the Middle East and North Africa [1]. The date is a berry composed of a fleshy mesocarp, covered by a thin epicarp and an endocarp that covers all of its seed. The seed is usually oblong and ventrally grooved, containing a small embryo and a hard endosperm [2]. Date seeds have been studied, but little used, and are still considered as an agricultural waste in many developing countries [3].

The date seed constitutes between 6 and $18 \%$ of the total weight of a mature date $[4,5]$, varying according to the variety and agroclimatic conditions of its cultivation. The seed contains sugars, appreciable amounts of minerals, high fiber content, and low contents of protein and fatty acids [6]. Due to its nutritional attributes, it has been used as food for cattle, horses, sheep, goats, camels, and poultry [2]. People also consume coffee-like drinks prepared from the seeds [7], and the use of ground seeds has been suggested in the preparation of certain processed foods [8]. Oil extraction has been one of the main alternative uses of the date seed, with possible applications in the pharmaceutical, food, and cosmetic industries [9]. Options have been explored for its use in the production of biofuels, particularly for the generation of biodiesel [3]. In the medical field, the date seed has great value as an agent with antioxidant, anti-inflammatory and antiviral activities [10].

Date producers are increasingly aware of the need to obtain a higher quality fruit in order to be more competitive in the market. Therefore, they have focused on identifying the male cultivars that have the greatest effects on the quality parameters in the fruit. Recent studies on the fruit of the 'Medjool' date cultivar in Mexico have concluded that there is a significant influence of pollen source on fruit physical and nutritional parameters [11,12].

Every year, interest in the cultivation of date palms increases in Mexico [13]. Much work has been done to improve date cultivation techniques and increase the efficiency of fertilization in order to obtain better yields. In 2018, Mexico produced 8945 tons of dates, of which $94 \%$ were the 'Medjool' cultivar $[13,14]$. The date industry in Mexico has not yet identified a potential use for date seeds, therefore, after the fruit has been consumed, the seeds are discarded. This is possibly due to the lack of knowledge about the nutritional properties of date seeds and the lack of research on this subject. Likewise, the possible use of date seeds as a source of cattle feed has been ruled out by large cattle producers, because a large volume of seeds is required, so its crushing was not affordable for use as a complementary food. In order to value the seed as a by-product, it is necessary to document its nutritional value and to explore possible industrial and medicinal applications.

Several studies have focused on determining the chemical properties of the date seed $[1,2,4,10]$. However, none has addressed the effect of various pollen sources on the chemical composition of the seed. The objective of this study was to characterize the effect of four different pollen sources on the chemical composition of the seed of the 'Medjool' cultivar under the soil and climatic conditions of the northwestern part of Mexico.

\section{Materials and Methods}

\subsection{Characterization of the Experimental Area}

The experiment was conducted in an orchard of 15 ha with organic certification (Figure 1B) located in "Rancho La Vaca" in the San Luis Rio Colorado Valley of Northwest Mexico (Sonora State) with the geographical coordinates: latitude $32^{\circ} 23^{\prime} 5^{\prime \prime} \mathrm{N}$, longitude $114^{\circ} 53^{\prime} 55^{\prime \prime} \mathrm{W}$ and average altitude of $45 \mathrm{~m}$. The soil is classified as alluvial from the dry bed of the Colorado River. Flood irrigation was used and distributed in six irrigations of $15 \mathrm{~cm}$ each during the year.

\subsection{Plant Materials, Treatments, and Experimental Design}

Four vigorous 17-year-old elite male date palms derived from offshoots of the most common cultivars in the area ('Deglet Noor', 'Khadrawy', 'Medjool', and 'Zahidi') were used as pollen sources 
for pollination of the 'Medjool' cultivar. Once the spathes naturally broke, they were removed and transported to a drying area, where they were hung for a period of 3 days for the extraction of pollen, which was extracted daily on a paper bed. The pollen was stored at $4{ }^{\circ} \mathrm{C}$ until pollination time. Four 16-year-old female 'Medjool' palms derived from offshoots of the 'Medjool' cultivar were randomly selected as recipients. Palms were planted with an $8 \times 8$ m distance between and within rows. After the natural cracking of their spathes, each spathe was manually opened. Four groups of three bunches (female inflorescences) were selected on each female tree, and each group was pollinated individually only once, using pollen from only one cultivar. Pollination was carried out manually using a brush between the second and fourth day after the spathes opened (Figure 1A). The fresh pollen was diluted with wheat flour in a 1:1 ratio. Additionally, one more plant was selected and managed as a control, using a traditional farmer's method, consisting of taking pollen from various unknown male palms that are compatible with the 'Medjool' female, mixing all the pollen, and diluting it to a 1:1 ratio with commercial wheat flour. Finally, each strand was thinned in all bunches at a rate of 12 dates per thread and 50 strands per bunch. [11]. The experimental design employed was a completely randomized design. In our case, this design was represented by four palms as replicates and four pollen sources. Each pollen treatment was applied to three randomly selected bunches on each palm.
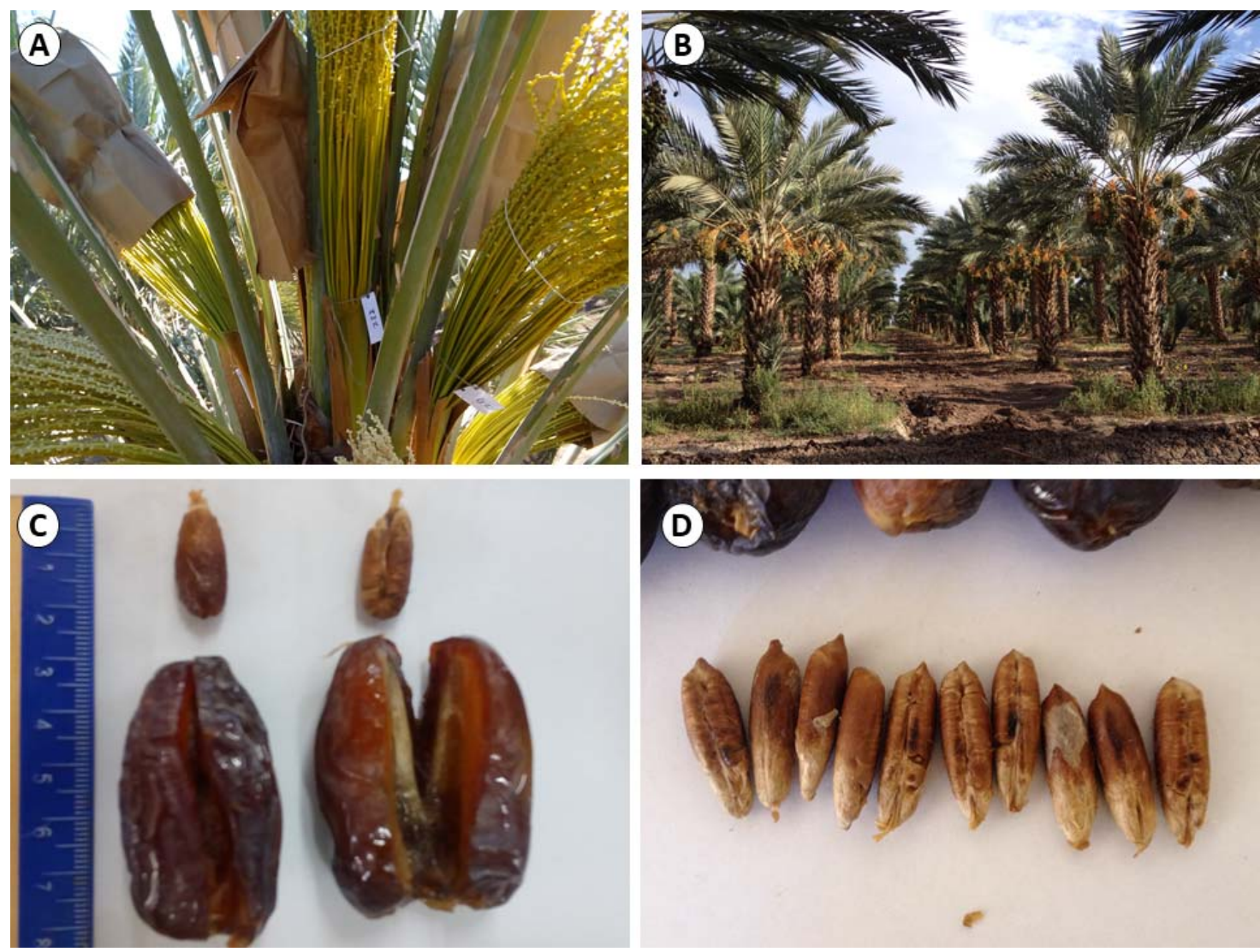

Figure 1. Experimental area and seed extraction. (A) Female inflorescences covered with paper bags after pollination to avoid contamination with other pollen sources. (B) Panoramic view of the plantation 50 days after pollination. (C) Removing the seed of the ripe fruit. (D) Sample of seeds extracted from the pollinated fruit with the 'Zahidi' pollen source.

\subsection{Physical Properties}

For each treatment (pollen source) in each palm, 15 fruit were collected from among its three bunches (60 fruit per treatment per palm), resulting in a total of 240 fruit among the four palms. From the control palm, 60 fruit were taken randomly from among its bunches. The fruit were weighed, 
then the seeds were removed (Figure 1C,D) and weighed with an electronic scale. Length and diameter were measured as well.

\subsection{Proximate Analysis}

Derived from the sampling performed in Section 2.3, nine samples (seeds) were taken randomly from each treatment of the four palms and the control, for a total of 45 samples; proximate analysis and three replicate measurements from each sample were made. All seeds (fresh) were incubated at $105{ }^{\circ} \mathrm{C}$ for $24 \mathrm{~h}$ to determine the moisture content. The samples were then incinerated at $550{ }^{\circ} \mathrm{C}$ for $8 \mathrm{~h}$ in a muffle oven and the ash percentage was calculated by weight difference [15]. The crude protein was obtained using a chemical digestion process (Kjeldahl method) to determine total nitrogen followed by conversion to protein percentage [15] using a conversion factor of 6.25 [16]. Total lipids were determined according to the method of Folch et al., (1957) [17]. Determination of dietary fiber was carried out using the AOAC enzymatic-gravimetric official method (Method 991.43) [18]. The $\mathrm{pH}$ was taken from a homogeneous sample at $20^{\circ} \mathrm{C}$ using a MP $744 \mathrm{pH}$ meter (Metrohm AG, Herisau, Switzerland). Total insoluble and soluble solids were determined using a refractometer to obtain ${ }^{\circ}$ Brix [19]. The total acidity was calculated titrating against $0.1 \mathrm{~N} \mathrm{NaOH}$ and was expressed as malic acid percentage. All the elements were expressed in $\mathrm{g} / 100 \mathrm{~g}$ dry weight.

\subsection{Sugars Determination}

From the samples in Section 2.3, five seeds from each treatment and control were taken (that is, 25 seeds in total) and three replicate measurements of sugars content were made for each sample. Total sugars and reducing sugars were determined using the Lane and Eynon volumetric method [20]. Non-reducing sugars were calculated as the difference between total sugars and reducing sugars.

\subsection{Minerals Analysis}

The mineral content was determined using standard methods [18]. From the samples in Section 2.3, three seeds from each treatment and control were taken (that is, 15 seeds in total) and three replicates from each sample were used for the mineral analysis. Each seed was converted to ash at $550{ }^{\circ} \mathrm{C}$ for $24 \mathrm{~h}$. Then $1 \mathrm{~g}$ of ash from each sample was dissolved in $5 \mathrm{~mL}$ of analytical grade hydrochloric acid $(20 \%)$ and the solution was transferred to a $50 \mathrm{~mL}$ volumetric flask. The final volume was completed using deionized water. Total minerals were determined using an atomic absorption spectrophotometer (model 4200 MPAES, Agilent Technologies, Santa Clara, CA, USA) and were expressed in mg/100 g dry weight basis.

\subsection{Antioxidant Activities and Total Phenols}

From the samples in Section 2.3, five seeds from each treatment and control were taken (that is, 25 seeds in total) and three replicates for each were used. The radical scavenging profile from each date seed was determined by three methods: DPPH scavenging activity [21], ABTS radical cation decolorization assay [22,23], and oxidation of $\beta$-carotene and linoleic acid system [24]. DPPH and ABTS are expressed as $\mathrm{IC}_{50} \mathrm{~g} / \mathrm{L}$ (half maximal inhibitory concentration), which means how much extract is needed to reduce $50 \%$ of the compound. Total phenols were determined using the Folin-Ciocalteu method [25]. The results were expressed as milligrams of equivalent gallic acid per $100 \mathrm{~g}$ dry weight (mg GAE/100 g dw).

\subsection{Energy Value Determination}

The energy values of the seed for each treatment were calculated using the percentages of crude protein, fat, and carbohydrate: Energy value $(\mathrm{kcal} / 100 \mathrm{~g})=(2.62 \times \%$ protein $)+(8.37 \times \%$ fat $)+$ (4.2 $\times \%$ carbohydrates) [26]. 


\subsection{Statistical Analysis}

The data were statistically analyzed using one-way ANOVA test in a balanced design. The means of the treatments were compared according to the least significant differences (LSD) test, at a significance level of 5\% [27]. The variance analysis was calculated using version 3.6.1 of Statistical Software R [28,29]. The final results were defined as mean values \pm standard deviation of three separate determinations by sample.

\section{Results}

\subsection{Physical Characteristics of Seed}

Table 1 shows the significant variations in the physical characteristics of the 'Medjool' date seed. The highest average seed weight was obtained with 'Medjool' pollen. This average weight does not show a significant difference compared to the rest of the treatments, except for 'Deglet Noor', which had the lowest average. Seeds from the control had an average weight significantly lower than any of the other treatments. The maximum seed length was obtained by the 'Khadrawy' treatment. The shortest seed lengths were obtained by the 'Deglet Noor' treatment and control. The average diameter of the seed did not show significant differences among the four pollen sources. However, the control had a significantly lower average diameter than that induced by the other pollen sources used in this study. The seed represents a small percentage of the total mass of the date fruit. In this study, the highest percentage of seed mass in the fruit was induced by the pollen of the 'Medjool' cultivar, while the lowest value corresponded to the 'Khadrawy' cultivar. The seed mass of the control was significantly smaller than any of the treatments. The results indicate that the pollen source has a significant effect on the physical characteristics of date seeds and all of the treatments significantly increase its weight as compared to the pollen used by the farmer.

Table 1. Physical characteristics of 'Medjool' date seeds obtained from fruit resulting from pollination using pollen from 'Deglet Noor', 'Khadrawy', 'Medjool', and 'Zahidi' cultivars. Control is a pollen mixture from random date palm male plants used by the grower.

\begin{tabular}{cccccc}
\hline Parameter & 'Deglet Noor' & 'Khadrawy' & 'Medjool' & 'Zahidi' & 'Control' \\
\hline Weight $(\mathrm{g})$ & $1.32 \pm 0.079 \mathrm{~b}$ & $1.38 \pm 0.074 \mathrm{ab}$ & $1.41 \pm 0.076 \mathrm{a}$ & $1.34 \pm 0.054 \mathrm{ab}$ & $1.22 \pm 0.113 \mathrm{c}$ \\
Length $(\mathrm{cm})$ & $2.53 \pm 0.128 \mathrm{c}$ & $2.71 \pm 0.085 \mathrm{a}$ & $2.64 \pm 0.15 \mathrm{ab}$ & $2.57 \pm 0.067 \mathrm{bc}$ & $2.51 \pm 0.131 \mathrm{c}$ \\
Diameter $(\mathrm{cm})$ & $0.88 \pm 0.029 \mathrm{a}$ & $0.89 \pm 0.029 \mathrm{a}$ & $0.91 \pm 0.019 \mathrm{a}$ & $0.88 \pm 0.034 \mathrm{a}$ & $0.84 \pm 0.043 \mathrm{~b}$ \\
\% of mass in the fruit & $5.61 \pm 0.3 \mathrm{c}$ & $5.36 \pm 0.8 \mathrm{c}$ & $6.16 \pm 0.5 \mathrm{a}$ & $5.88 \pm 0.4 \mathrm{~b}$ & $5.06 \pm 0.3 \mathrm{~d}$ \\
\hline
\end{tabular}

Values are mean \pm SD of 60 samples per treatment and control. Means followed by same letter(s) in a row do not differ significantly at 0.05 probability level.

\subsection{Proximate Composition of the Seed}

The proximate composition of the seeds is summarized in Table 2. A significantly higher moisture content was observed in the 'Medjool' treatment. The lowest moisture content was from the 'Deglet Noor' treatment, which was significantly lower than the 'Khadrawy' treatment and control. The protein content in the seed was significantly higher for the 'Khadrawy' treatment. The 'Deglet Noor' and 'Zahidi' treatments had protein contents significantly lower than the control and that of 'Medjool' treatment. Significant differences among the four cultivars were observed for the lipid concentration. The highest average was for the 'Medjool' treatment, whereas the lowest was for the 'Zahidi' and 'Deglet Noor' treatments. The control showed the lowest lipid concentration of all treatments. The influence of pollen sources had a significant effect on the dietary fiber content. The highest average was for the 'Khadrawy' treatment and the lowest average value was for the 'Zahidi' treatment. The control resulted in an average significantly lower than all other treatments. The highest ash content was for the 'Deglet Noor' treatment, being significantly higher than the rest of the treatments. The lowest ash 
content was obtained from the 'Medjool' treatment. Finally, the ash content in the control was not significantly different compared to 'Medjool' treatment.

Table 2. Proximate composition of 'Medjool' date seeds obtained from fruit resulting from pollination using pollen from 'Deglet Noor', 'Khadrawy', 'Medjool', and 'Zahidi' cultivars. Control is a pollen mixture from random date palm male plants used by the grower.

\begin{tabular}{cccccc}
\hline Parameter & 'Deglet Noor' & 'Khadrawy' & 'Medjool' & 'Zahidi' & 'Control' \\
\hline Moisture (\%) ${ }^{\mathrm{a}}$ & $4.90 \pm 0.22 \mathrm{c}$ & $5.89 \pm 0.23 \mathrm{ab}$ & $6.36 \pm 0.32 \mathrm{a}$ & $5.40 \pm 0.40 \mathrm{bc}$ & $5.69 \pm 0.12 \mathrm{~b}$ \\
Protein $(\mathrm{g} / 100 \mathrm{~g}){ }^{\mathrm{b}}$ & $4.44 \pm 0.12 \mathrm{c}$ & $5.49 \pm 0.14 \mathrm{a}$ & $4.99 \pm 0.15 \mathrm{~b}$ & $4.50 \pm 0.14 \mathrm{c}$ & $4.82 \pm 0.05 \mathrm{~b}$ \\
Lipids $(\mathrm{g} / 100 \mathrm{~g}){ }^{\mathrm{b}}$ & $9.63 \pm 0.07 \mathrm{c}$ & $9.98 \pm 0.18 \mathrm{~b}$ & $10.19 \pm 0.14 \mathrm{a}$ & $9.62 \pm 0.08 \mathrm{c}$ & $9.32 \pm 0.11 \mathrm{~d}$ \\
Dietary fiber $(\mathrm{g} / 100 \mathrm{~g})^{\mathrm{b}}$ & $69.37 \pm 5.42 \mathrm{ab}$ & $72.59 \pm 1.74 \mathrm{a}$ & $65.56 \pm 2.41 \mathrm{~b}$ & $59.65 \pm 4.19 \mathrm{c}$ & $52.31 \pm 4.32 \mathrm{~d}$ \\
Ash $(\mathrm{g} / 100 \mathrm{~g})^{\mathrm{b}}$ & $1.42 \pm 0.27 \mathrm{a}$ & $1.27 \pm 0.28 \mathrm{ab}$ & $1.09 \pm 0.40 \mathrm{bc}$ & $1.20 \pm 0.04 \mathrm{ab}$ & $0.96 \pm 0.02 \mathrm{c}$ \\
\hline
\end{tabular}

Values are mean \pm SD of nine samples per treatment and control with three independent determinations per sample. Means followed by same letter(s) in a row do not differ significantly at 0.05 probability level. ${ }^{a}$ Expressed on fresh weight basis. ${ }^{b}$ Expressed on dry weight basis.

\subsection{Content of Total Soluble Solids, Insoluble Solids, Total Acidity, and pH.}

The averages of the total soluble solids, insoluble solids, total acidity and $\mathrm{pH}$, are shown in Table 3 . A significantly higher average of total soluble solids (TSS) was observed in the 'Zahidi' treatment. The lowest significant TSS content was for 'Medjool' and 'Khadrawy' treatments. The control was not significantly different than these last two treatments. The highest significant content of insoluble solids was for the 'Khadrawy' and 'Medjool' treatments, and control, compared to the other cultivars, but was not significant among them. The 'Zahidi' treatment showed the lowest insoluble solids content, differing from the rest of the treatments. The sources of pollen did not have a significant effect on the total acidity and $\mathrm{pH}$. No studies were found that described these same parameters for the 'Medjool' cultivar grown in other countries.

Table 3. Content of total soluble solids, insoluble solids, total acidity, and pH of 'Medjool' date seeds obtained from fruit resulting from pollination using pollen from 'Deglet Noor', 'Khadrawy', 'Medjool', and 'Zahidi' cultivars. Control is a pollen mixture from random date palm male plants used by the grower. All parameters are expressed in $\mathrm{g} / 100 \mathrm{~g}$ dry weight.

\begin{tabular}{cccccc}
\hline Parameter & 'Deglet Noor' & 'Khadrawy' & 'Medjool' $^{\prime}$ & 'Zahidi' & 'Control' \\
\hline Total soluble solids & $6.00 \pm 0.05 \mathrm{~b}$ & $4.13 \pm 0.23 \mathrm{c}$ & $4.03 \pm 0.08 \mathrm{c}$ & $7.94 \pm 0.05 \mathrm{a}$ & $4.08 \pm 0.13 \mathrm{c}$ \\
Insoluble solids & $94.35 \pm 0.29 \mathrm{~b}$ & $96.03 \pm 0.05 \mathrm{a}$ & $95.69 \pm 0.57 \mathrm{a}$ & $92.21 \pm 0.31 \mathrm{c}$ & $96.13 \pm 0.21 \mathrm{a}$ \\
Total acidity & $0.052 \pm 0.03 \mathrm{a}$ & $0.053 \pm 0.04 \mathrm{a}$ & $0.052 \pm 0.07 \mathrm{a}$ & $0.052 \pm 0.02 \mathrm{a}$ & $0.053 \pm 0.02 \mathrm{a}$ \\
pH & $6.98 \pm 0.02 \mathrm{a}$ & $6.96 \pm 0.04 \mathrm{a}$ & $7.00 \pm 0.02 \mathrm{a}$ & $6.95 \pm 0.05 \mathrm{a}$ & $7.02 \pm 0.03 \mathrm{a}$ \\
\hline
\end{tabular}

Values are mean \pm SD of nine samples per treatment and control with three independent determinations per sample. Means followed by same letter(s) in a row do not differ significantly at 0.05 probability level.

\subsection{Sugar Content}

The effect of the four treatments on the average sugar content was statistically significant (Table 4). Total sugar content was significantly higher for the 'Deglet Noor' treatment, while the 'Zahidi' treatment was the lowest, being significantly less than the control. For reducing sugars, the highest significant percentage was reached by the 'Khadrawy' treatment, whereas the lowest was for the 'Zahidi' treatment. The control showed the second highest average. Non-reducing sugars were significantly affected by the different pollen sources. The highest percentage was obtained in 'Deglet Noor'-pollinated fruit, while the lowest was obtained from the 'Zahidi' treatment, which was lower than the control. Unlike the high sugar content in the date pulp, the seed has a very low sugar content. Finally, the highest energy content corresponded to the 'Medjool' cultivar, while the lowest was from the 'Zahidi' treatment. 
Table 4. Sugar content and energy content of 'Medjool' date seeds obtained from fruit resulting from pollination using pollen from 'Deglet Noor', 'Khadrawy', 'Medjool', and 'Zahidi' cultivars. Control is a pollen mixture from random date palm male plants used by the grower. All parameters are expressed in $\mathrm{g} / 100 \mathrm{~g}$ dry weight.

\begin{tabular}{cccccc}
\hline Parameter & 'Deglet Noor' & 'Khadrawy' $^{\prime}$ & 'Medjool' $^{\prime}$ & 'Zahidi' & 'Control' $^{\prime}$ \\
\hline Total sugars & $6.96 \pm 0.21 \mathrm{a}$ & $5.75 \pm 0.23 \mathrm{c}$ & $6.22 \pm 0.12 \mathrm{~b}$ & $4.50 \pm 0.11 \mathrm{e}$ & $5.42 \pm 0.07 \mathrm{~d}$ \\
Reducing sugars & $4.24 \pm 0.03 \mathrm{c}$ & $5.06 \pm 0.02 \mathrm{a}$ & $4.20 \pm 0.08 \mathrm{c}$ & $4.08 \pm 0.05 \mathrm{~d}$ & $4.58 \pm 0.11 \mathrm{~b}$ \\
Non-Reducing sugars & $1.72 \pm 0.03 \mathrm{a}$ & $1.51 \pm 0.11 \mathrm{~b}$ & $1.50 \pm 0.14 \mathrm{~b}$ & $1.07 \pm 0.15 \mathrm{~d}$ & $1.30 \pm 0.14 \mathrm{c}$ \\
Energetic value $^{\mathrm{a}}$ & $122.32 \pm 0.78 \mathrm{~b}$ & $121.96 \pm 1.66 \mathrm{~b}$ & $125.26 \pm 0.76 \mathrm{a}$ & $112.40 \pm 0.96 \mathrm{~d}$ & $114.03 \pm 0.59 \mathrm{c}$ \\
\hline
\end{tabular}

Values are mean \pm SD of five samples per treatment and control with three independent determinations per sample. Means followed by same letter(s) in a row do not differ significantly at 0.05 probability level. ${ }^{\text {a }}$ Expressed in $\mathrm{Kcal} / 100 \mathrm{~g}$.

\subsection{Macronutrient Content}

Table 5 shows the macronutrient content of date seeds, where significant differences were observed among the treatments. The potassium content was the highest and was followed in descending order by sulfur, phosphorus, calcium, magnesium, and sodium. 'Zahidi' pollen induced the highest content of sulfur, phosphorus, magnesium, and sodium, while 'Khadrawy' and control induced it for potassium content, and 'Medjool' for calcium content. The lowest significant content for sulfur, phosphorus and magnesium resulted from the 'Medjool' treatment, for potassium and calcium from the 'Zahidi' treatment, and for sodium from the 'Khadrawy' treatment. The control produced the highest average value for potassium and sulfur, but the lowest for calcium, compared to the other treatments.

Table 5. Total macrominerals content for four pollen source treatments and control for a recipient 'Medjool' cultivar. Control is a pollen mixture from random date palm male plants, used by the grower. All parameters are expressed in $\mathrm{mg} / 100 \mathrm{~g}$ dry weight.

\begin{tabular}{cccccc}
\hline Parameter & 'Deglet Noor' & 'Khadrawy' & 'Medjool' $^{\prime}$ & 'Zahidi' & 'Control' $^{\prime}$ \\
\hline Potassium & $425.87 \pm 13.6 \mathrm{c}$ & $459.79 \pm 16.9 \mathrm{~b}$ & $414.21 \pm 15.2 \mathrm{~d}$ & $399.97 \pm 12.6 \mathrm{~d}$ & $461.06 \pm 11.1 \mathrm{a}$ \\
Sulfur & $147.21 \pm 2.8 \mathrm{c}$ & $160.05 \pm 2.4 \mathrm{~b}$ & $135.51 \pm 4.8 \mathrm{c}$ & $162.67 \pm 1.5 \mathrm{~b}$ & $190.64 \pm 2.9 \mathrm{a}$ \\
Phosphorus & $87.70 \pm 2.6 \mathrm{c}$ & $92.84 \pm 2.06 \mathrm{ab}$ & $79.43 \pm 2.1 \mathrm{bc}$ & $96.71 \pm 2.4 \mathrm{a}$ & $93.44 \pm 2.3 \mathrm{ab}$ \\
Calcium & $56.75 \pm 1.3 \mathrm{~b}$ & $53.94 \pm 0.9 \mathrm{c}$ & $62.16 \pm 1.10 \mathrm{a}$ & $51.35 \pm 1.06 \mathrm{~d}$ & $47.02 \pm 1.5 \mathrm{e}$ \\
Magnesium & $35.21 \pm 1.9 \mathrm{~b}$ & $36.72 \pm 2.1 \mathrm{~b}$ & $31.85 \pm 2.03 \mathrm{c}$ & $40.71 \pm 3.1 \mathrm{a}$ & $35.02 \pm 2.5 \mathrm{~b}$ \\
Sodium & $32.10 \pm 0.9 \mathrm{c}$ & $28.60 \pm 0.5 \mathrm{~d}$ & $33.50 \pm 1.6 \mathrm{~b}$ & $42.36 \pm 0.7 \mathrm{a}$ & $33.33 \pm 1.3 \mathrm{~b}$ \\
\hline
\end{tabular}

Values are mean \pm SD of three samples per treatment and control with three independent determinations per sample. Means followed by same letter(s) in a row do not differ significantly at 0.05 probability level.

\subsection{Micronutrient Content}

Table 6 shows the micronutrient contents found in date seeds, where significant differences were observed among the four treatments. The selenium content was the highest, followed in descending order by iron, silicon, zinc, copper, manganese, strontium, and aluminum. 'Zahidi' pollen induced the highest significant content for iron, zinc, copper, strontium, and aluminum. 'Medjool' pollen induced the highest levels of selenium and manganese, and 'Deglet Noor' pollen the highest silicon level. The lowest significant contents of iron, manganese, strontium, and aluminum resulted from 'Deglet Noor' pollen, and selenium and silicon from 'Zahidi' pollen. The lowest zinc and copper contents wereassociated with the 'Medjool' treatment. The control had the highest average contents of iron, zinc, manganese, and aluminum, but the lowest of strontium, compared to the rest of the treatments. 
Table 6. Total microminerals content for four pollen source treatments and control for a recipient 'Medjool' cultivar. Control is a pollen mixture from random date palm male plants, used by the grower. All parameters are expressed in $\mathrm{mg} / 100 \mathrm{~g}$ dry weight.

\begin{tabular}{cccccc}
\hline Parameter & 'Deglet Noor' & 'Khadrawy' & 'Medjool' $^{\prime}$ & 'Zahidi' & 'Control' \\
\hline Selenium & $3.91 \pm 0.11 \mathrm{~b}$ & $4.14 \pm 0.04 \mathrm{a}$ & $4.33 \pm 0.12 \mathrm{a}$ & $3.77 \pm 0.08 \mathrm{~b}$ & $4.08 \pm 0.08 \mathrm{a}$ \\
Iron & $1.05 \pm 0.01 \mathrm{c}$ & $1.10 \pm 0.01 \mathrm{c}$ & $1.30 \pm 0.03 \mathrm{~b}$ & $1.45 \pm 0.02 \mathrm{~b}$ & $1.68 \pm 0.03 \mathrm{a}$ \\
Silicon & $0.85 \pm 0.06 \mathrm{a}$ & $0.80 \pm 0.09 \mathrm{a}$ & $0.75 \pm 0.01 \mathrm{~b}$ & $0.62 \pm 0.08 \mathrm{c}$ & $0.77 \pm 0.09 \mathrm{~b}$ \\
Zinc & $0.78 \pm 0.01 \mathrm{~d}$ & $1.01 \pm 0.07 \mathrm{c}$ & $0.70 \pm 0.04 \mathrm{~d}$ & $1.18 \pm 0.04 \mathrm{~b}$ & $1.37 \pm 0.03 \mathrm{a}$ \\
Copper & $0.77 \pm 0.05 \mathrm{c}$ & $0.75 \pm 0.06 \mathrm{c}$ & $0.67 \pm 0.03 \mathrm{~d}$ & $0.91 \pm 0.10 \mathrm{a}$ & $0.88 \pm 0.08 \mathrm{~b}$ \\
Manganese & $0.56 \pm 0.01 \mathrm{~d}$ & $0.63 \pm 0.03 \mathrm{~cd}$ & $0.91 \pm 0.01 \mathrm{~b}$ & $0.79 \pm 0.02 \mathrm{c}$ & $1.16 \pm 0.03 \mathrm{a}$ \\
Strontium & $0.25 \pm 0.01 \mathrm{bc}$ & $0.26 \pm 0.02 \mathrm{~b}$ & $0.28 \pm 0.02 \mathrm{a}$ & $0.29 \pm 0.01 \mathrm{a}$ & $0.21 \pm 0.01 \mathrm{~d}$ \\
Aluminum & $0.18 \pm 0.01 \mathrm{~d}$ & $0.25 \pm 0.01 \mathrm{~b}$ & $0.20 \pm 0.01 \mathrm{c}$ & $0.36 \pm 0.01 \mathrm{a}$ & $0.37 \pm 0.01 \mathrm{a}$ \\
\hline
\end{tabular}

Values are mean \pm SD of three samples per treatment and control with three independent determinations per sample. Means followed by same letter(s) in a row do not differ significantly at 0.05 probability level.

\subsection{Antioxidant Activity and Phytochemical Evaluation}

Significant differences were observed among the four treatments for total phenolic content and antioxidant activities (Table 7). The maximum significant $\beta$-Carotene percent was induced by pollen of the 'Deglet Noor' cultivar, whereas the lowest value was induced by the 'Medjool' pollen. The control resulted in the second highest percentage compared to the rest of the treatments. DPPH results had the highest significant value for the 'Zahidi' treatment, while the lowest significant value was for the 'Medjool' treatment. The control resulted in the third highest value of DPPH with respect to the four treatments. The highest value of the ABTS assay resulted from the 'Khadrawy' treatment, and the lowest from the 'Medjool' treatment. The control showed the third highest result with respect to the four treatments and was not significantly different from the 'Khadrawy' and 'Zahidi' treatments. Regarding the total phenolic content, the 'Khadrawy' pollen treatment induced the highest content, whereas the lowest significant total phenolic content was obtained from the 'Deglet Noor' treatment. However, the control had the third highest content with respect to the four treatments.

Table 7. Total phenolic content and antioxidants activities for 'Medjool' date seeds, obtained from fruit resulting from pollination using pollen from 'Deglet Noor', 'Khadrawy', 'Medjool', and 'Zahidi' cultivars. Control is a pollen mixture from random date palm male plants used by the grower.

\begin{tabular}{|c|c|c|c|c|c|}
\hline Parameter & 'Deglet Noor' & 'Khadrawy' & 'Medjool' & 'Zahidi' & 'Control' \\
\hline$\beta$-Carotene $(\%)$ & $62.33 \pm 3.52 a$ & $46.01 \pm 5.19 b$ & $33.66 \pm 3.78 b$ & $50.58 \pm 5.50 \mathrm{a}$ & $52.25 \pm 7.66 a$ \\
\hline $\mathrm{DPPH}\left(\mathrm{IC}_{50} \mathrm{~g} / \mathrm{L}\right)$ & $0.0023 \pm 0.0008 c$ & $0.0055 \pm 0.0004 \mathrm{~b}$ & $0.0014=$ & $0.0094 \pm 0.0021 \mathrm{a}$ & $0.0032 \pm 0.0006 \mathrm{bc}$ \\
\hline $\mathrm{ABTS}\left(\mathrm{IC}_{50} \mathrm{~g} / \mathrm{L}\right)$ & $0.199 \pm 0.016 \mathrm{ab}$ & $0.299 \pm 0.005 \mathrm{a}$ & $0.176 \pm 0.072 \mathrm{~b}$ & $0.278 \pm 0.003 a$ & $0.057 \mathrm{a}$ \\
\hline Total phenolic contentppppp(mg GAE/100 g, DW) & $11.44 \pm 0.36 \mathrm{~d}$ & $18.26 \pm 0.50 \mathrm{ab}$ & $16.03 \pm 0.75 b c$ & $12.75 \pm 0.16 \mathrm{~d}$ & $14.25 \pm 0.80 \mathrm{~b}$ \\
\hline
\end{tabular}

Values are mean \pm SD of five samples per treatment and control with three independent determinations per sample. Means followed by same letter(s) in a row do not differ significantly at 0.05 probability level.

\section{Discussion}

The pollen sources selected for this study had an effect on the physicochemical properties of the seeds of the 'Medjool' date cultivar. However, some of the parameters (diameter, total acidity, $\mathrm{pH}$ ) did not show statistically significant differences. In previous studies carried out in Mexico, under the same conditions, it was determined that the pollen from the 'Khadrawy' cultivar influenced most of the analyzed physico-chemical characteristics of 'Medjool' fruit [11,12].

Previous studies in Morocco [30] and the United Arab Emirates [31] quantified the physical properties of seeds of the date cultivar 'Medjool'. The variations in seed characteristics reported from these studies and ours can be attributed to various factors in addition to pollens, such as environment, irrigation, climate, and fertilization, among others.

A high range of dietary fiber content $(52.31-72.59 \mathrm{~g} / 100 \mathrm{~g})$ for all treatments in this study was identified in the seed of the 'Medjool' date (Table 2). Therefore, date seeds could potentially be used as an ingredient in the production of food for human consumption in which there is a need to increase 
the fiber content, such as wheat flour-based products [31]. This would stimulate solid waste transit in the body, to possibly prevent constipation and some gastrointestinal diseases [10,30].

The date seed is characterized by having a low protein content, which can vary between 4 and $6 \mathrm{~g} / 100 \mathrm{~g}$ according to the seed variety [30,31]. In this study, its average value was $4.5 \mathrm{~g} / 100 \mathrm{~g}$ (Table 2) for the seed of 'Medjool'. Although low, the seed protein content is higher than the content of protein in the pulp of the fruit [12].

Likewise, the seed contains a low lipid content (Table 2), resulting in little commercial potential for industrial oil extraction [9]. However, a great advantage for its exploitation is that this material, being considered an agricultural waste, can be acquired at a very low cost or without any cost. The percentage of the most abundant fatty acids in the seed of the 'Medjool' date was reported in a study from Israel [9] as $44.92 \%$ oleic and $21.8 \%$ lauric, while a study from Morocco [30] reported $44.92 \%$ oleic and $20.34 \%$ lauric. Oleic and lauric acids were followed by myristic, palmitic, and linoleic acids in lower proportions. Date seed oil has already been used to replace portions of other vegetable oils in products such as body creams, shampoos, bar soaps, and shaving creams [9]. Another study reported that date seed oil used in mayonnaise production produced a superior sensory characteristic compared to another vegetable oil [32]. Based on last year's date production in Mexico [14] and the percentage of lipids in the date seed reported in this study (Table 2), almost 894 tons of date seed oil could be produced. Therefore, the operation of a small oil extraction plant may be feasible in Mexico. Table 8 shows the average values of the physical parameters and proximal composition of 'Medjool' date seeds obtained from the four treatments (pollen sources: 'Deglet Noor', 'Khadrawy', 'Medjool', and 'Zahidi') in this study compared to those reported by studies carried out in Morocco [30] and United Arab Emirates [31].

Table 8. Comparative analysis of the physical characteristics and proximal composition of the average obtained from the four treatments used in this study, against studies developed in the Medjool seeds in Morocco and the United Arab Emirates.

\begin{tabular}{|c|c|c|c|}
\hline Parameter & Average for This Study ${ }^{a}$ & Morocco [30] & United Arab Emirates [31] \\
\hline Weight (g) & 1.36 & 1.10 & - \\
\hline Length $(\mathrm{cm})$ & 2.61 & 2.09 & 2.75 \\
\hline Diameter $(\mathrm{cm})$ & 0.89 & 0.93 & 1.15 \\
\hline$\%$ of mass in the fruit & 5.75 & 7.48 & 7.29 \\
\hline Moisture (\%) ${ }^{b}$ & 5.63 & 9.79 & 8.25 \\
\hline Protein $(g / 100 \mathrm{~g})^{c}$ & 4.85 & 5.55 & 6.14 \\
\hline Lipids $(g / 100 \mathrm{~g})^{\mathrm{c}}$ & 9.85 & 6.52 & 5.66 \\
\hline Dietary fiber $(g / 100 \mathrm{~g})^{\mathrm{c}}$ & 66.79 & 19.90 & 73.36 \\
\hline Ash $(g / 100 g)^{c}$ & 1.24 & 1.14 & 1.09 \\
\hline
\end{tabular}

${ }^{a}$ The average was obtained by averaging all treatments (pollen sources) from this experiment. ${ }^{b}$ Expressed on fresh weight basis. ${ }^{c}$ Expressed on dry weight basis.

The insoluble solids content on average for this study was $94.64 \mathrm{~g} / 100 \mathrm{~g}$ for the seed (Table 3), much higher than the pulp content of the same fruit $(15.70 \mathrm{~g} / 100 \mathrm{~g})$ reported in another study under the same production conditions [12]. The average of the four treatments in total soluble solids and total acidity of 'Medjool' seeds were lower than the results reported for fruit by the study mentioned above; however, the $\mathrm{pH}$ turned out to be very similar to that of the 'Medjool' date fruit [12].

The study carried out in Morocco [30] reported a content of total sugars of $9.54 \mathrm{~g} / 100 \mathrm{~g} \mathrm{dw}$ and an energetic value of $103.58 \mathrm{Kcal} / 100 \mathrm{~g} \mathrm{dw}$ for the seed of 'Medjool'. In this study, an average of $5.85 \mathrm{~g} / 100 \mathrm{~g} \mathrm{dw}$ and $120.48 \mathrm{Kcal} / 100 \mathrm{~g} \mathrm{dw}$ for total sugars and energy value, respectively, are reported among the four pollen sources (Table 4). No other studies were found that reported the reducing and non-reducing sugar averages of seeds of the 'Medjool' cultivar. The sugar content in the seed of the 'Medjool' cultivar date is very small compared to that in the pulp of the same fruit (Table 4) [12].

The seeds of the 'Medjool' date are a good source of minerals, providing a greater amount of sulfur, sodium, iron, manganese, and zinc (Tables 5 and 6) than the pulp of the same fruit [12]. However, 
the contents of potassium, magnesium, calcium, and phosphorus in the seed (Table 5) are not as high as the contents found in the fruit [12]. Variations in the mineral content between studies conducted in Morocco [30] and the United Arab Emirates [31] compared to those reported in the present study can be attributed to factors involved in crop nutrition, such as the level of fertility in the soil and the amount and type of fertilizers applied to the palms [33]. Minerals are micronutrients that the body requires to develop various vital functions such as bone formation, hormone production, and metabolic processes. The intake of $100 \mathrm{~g}$ of date seed is capable of providing $14 \%$ of the recommended daily diet of iron, manganese, copper, and magnesium, as well as $7 \%$ and $4 \%$ of zinc and calcium, respectively [30]. Table 9 shows the average of the four treatments (pollen sources: 'Deglet Noor', 'Khadrawy', 'Medjool', and 'Zahidi') for most of the mineral contents reported in this study, compared them against those reported in studies carried out in Morocco [30], United Arab Emirates [31], and India [34].

Table 9. Comparative analysis minerals content of the average obtained from the four treatments used in this study, against studies developed in the Medjool seeds in Morocco, United Arab Emirates and India. All expressed in mg/100 g dry weight.

\begin{tabular}{ccccc}
\hline Parameter & Average for This Study $^{\text {a }}$ & Morocco [30] & United Arab Emirates [31] & India [34] \\
\hline Potassium & 424.96 & 296.71 & 240.33 & 181.33 \\
Phosphorus & 89.17 & - & 146.50 & 121.33 \\
Calcium & 56.05 & 22.70 & 23.00 & 39.49 \\
Magnesium & 36.12 & 82.76 & 74.92 & 28.00 \\
Sodium & 34.14 & 10.80 & 15.42 & - \\
Iron & 1.22 & 0.55 & 5.04 & 1.83 \\
Zinc & 0.91 & 1.47 & 1.62 & - \\
Copper & 0.77 & 0.83 & 0.21 & - \\
Manganese & 0.72 & 0.55 & 0.55 & - \\
Strontium & 0.27 & - & 0.88 & - \\
Aluminum & 0.24 & - & 1.88 & \\
\hline
\end{tabular}

${ }^{a}$ The average was obtained by averaging all treatments (pollen sources) from this experiment.

Another characteristic of the date seed is its high phenolic content and antioxidant activity. The average total phenolic content in the four treatments for 'Medjool' seed was found to be higher than that reported in the pulp of the same fruit [12]. The results of the antioxidant capacity reported by this study using the DPPH and ABTS tests for the seed were found to be lower against those reported in the pulp of the same fruit by another study [35]. DPPH results gave an average of $0.0046 \mathrm{IC}_{50} \mathrm{~g} / \mathrm{L}$ for this study (Table 7), while the study carried out in Morocco [30] reported $0.133 \mathrm{IC}_{50} \mathrm{~g} / \mathrm{L}$ for 'Medjool' seeds, showing a lower degree of antioxidant activity than in our study. An average of $14.62 \mathrm{mg} \mathrm{GAE} / 100 \mathrm{~g}$ in total phenolic content was found in this study, while the study in Morocco reported $30.78 \mathrm{mg}$ GAE/100 $\mathrm{g}$. The average of $\beta$-Carotene and ABTS were $48.14 \%$ and $0.238 \mathrm{IC}_{50} \mathrm{~g} / \mathrm{L}$, respectively, for the four treatments in this study (Table 7). No studies were found reporting the $\beta$-Carotene percentage, nor the concentration providing $50 \%$ inhibition $\left(\mathrm{IC}_{50}\right)$ for the ABTS assay in 'Medjool' seeds.

The functional components in food are nutrient materials of plant and microbial origin that stimulate human health. Dietary fiber, essential vitamins, and minerals are functional components that are characterized by antimicrobial, anticancer, antioxidant, and other activities [36]. The great nutritional potential of the date seed is mainly related to the significant amount of fiber content and its high polyphenol content, which are far superior to those contained in the pulp of the same fruit. Possible health benefits, such as the prevention of chronic diseases and the strengthening of the oxidative system of the human body, have been suggested to be derived from its antioxidant properties [4]. 


\section{Conclusions}

Considering the results obtained in this study, it could be concluded that pollen sources from the 'Khadrawy' and 'Medjool' cultivars had the most significant effects on the nutritional characteristics of the seed of the 'Medjool' date cultivar, compared to the other pollen sources. The analysis presented revealed that the 'Khadraway' pollen source increased the dietary fiber content by $28 \%$, phenols by $22 \%$ and protein by $13 \%$, whereas pollen of 'Medjool' increased lipid content by $9 \%$ compared to the traditional pollination practices of the farmer. Therefore, it may be recommended to use the pollen of 'Khadrawy' or 'Medjool' cultivars, mixed or separately, in order to obtain the best contents of fiber, minerals, lipids, and antioxidants in the seeds.

These nutritional components can give a high added value to the by-products that could be generated from this seed. This could stimulate the interest in its exploitation in Mexico, for its use in some functional foods for human consumption, as nutritional supplements in food for cattle and birds, and other formulations in the industries such as cosmetics and pharmaceuticals. This work is the first of its kind to characterize the effect that pollen from various sources has on the seed of the 'Medjool' date.

Author Contributions: R.S.-T., N.O.-U. and J.A.S.-U. conceived and designed the study, completed the fieldwork and wrote the paper; B.V.-S., C.G.-G. and S.N.-P. performed the experiments, contributed reagents/materials/analysis tools. D.H.-B., J.P.G.-V. and R.K. co-wrote the paper. All authors contributed to its editing and approved the final draft. All authors have read and agreed to the published version of the manuscript.

Funding: This research received no external funding.

Acknowledgments: We are grateful to Rafael Quirarte-Gutiérrez and Roberto Torres-Yescas from Corporativo RUVA, S. de R.L. de C.V. for allowing us access to their plantations and for the facilities granted to carry out this study.

Conflicts of Interest: The authors declare no conflict of interests.

\section{References}

1. Golshan Tafti, A.; Solaimani Dahdivan, N.; Yasini Ardakani, S.A. Physicochemical properties and applications of date seed and its oil. Int. Food Res. J. 2017, 24, 1399-1406.

2. Adeosun, A.M.; Oni, S.O.; Ighodaro, O.M.; Durosinlorun, O.H.; Oyedele, O.M. Phytochemical, minerals and free radical scavenging profiles of Phoenix dactilyfera L. seed extract. J. Taibah Univ. Med. Sci. 2016, 11, 1-6. [CrossRef]

3. Elnajjar, E.; Hasan, S.; Alnaqbi, A.H.; Al Omari, S.A.; Al-Zuhair, S. Optimizing the Extraction of Oils from Date Seeds for Biodiesel Production. Int. J. Environ. Res. 2018, 12, 101-108. [CrossRef]

4. Platat, C.; Habib, H.M.; Al Maqbali, F.D.; Jaber, N.N.; Ibrahim, W.H. Identification of Date Seeds Varieties Patterns to Optimize Nutritional Benefits of Date Seeds. J. Nutr. Food Sci. 2014, 8, 2. [CrossRef]

5. Abdul Afiq, M.J.; Abdul Rahman, R.; Che Man, Y.B.; Al-Kahtani, H.A.; Mansor, T.S.T. Date seed and date seed oil. Int. Food Res. J. 2013, 20, 2035-2043.

6. Al-Farsi, M.A.; Lee, C.Y. Usage of Date (Phoenix dactylifera L.) Seeds in Human Health and Animal Feed. In Nuts and Seeds in Health and Disease Prevention; Preedy, V., Watson, R., Patel, V., Eds.; Elsevier: London, UK, 2011; p. 1226. ISBN 9780123756886.

7. Ghnimi, S.; Almansoori, R.; Jobe, B.; Hassan, M.H.; Kamal-Eldin, A. Quality Evaluation of Coffee-Like Beverage from Date Seeds (Phoenix dactylifera, L.). J. Food Process. Technol. 2015, 6. [CrossRef]

8. Sirisena, S.; Ng, K.; Ajlouni, S. The Emerging Australian Date Palm Industry: Date Fruit Nutritional and Bioactive Compounds and Valuable Processing By-Products. Compr. Rev. Food Sci. Food Saf. 2015, 14, 813-823. [CrossRef]

9. Devshony, S.; Eteshola, E.; Shani, A. Characteristics and some potential applications of date palm (Phoenix dactylifera L.) seeds and seed oil. J. Am. Oil Chem. Soc. 1992, 69, 595-597. [CrossRef]

10. Shi, L.E.; Zheng, W.; Aleid, S.M.; Tang, Z.X. Date pits: Chemical composition, nutritional and medicinal values, utilization. Crop Sci. 2014, 54, 1322-1330. [CrossRef] 
11. Salomon-Torres, R.; Ortiz-Uribe, N.; Villa-Angulo, R.; Villa-Angulo, C.; Norzagaray-Plasencia, S.; Garcia-Verdugo, C.D. Effect of pollenizers on production and fruit characteristics of date palm (Phoenix dactylifera L.) cultivar Medjool in Mexico. Turk. J. Agric. For. 2017, 41, 338-347. [CrossRef]

12. Salomón-Torres, R.; Ortiz-Uribe, N.; Sol-Uribe, J.A.; Villa-Angulo, C.; Villa-Angulo, R.; Valdez-Salas, B.; García-González, C.; Monroy, C.G.I.; Norzagaray-Plasencia, S. Influence of different sources of pollen on the chemical composition of date (Phoenix dactylifera L.) cultivar Medjool in México. AJCS 2018, 12, 1835-2707. [CrossRef]

13. Ortiz-Uribe, N.; Salomón-Torres, R.; Krueger, R. Date Palm Status and Perspective in Mexico. Agriculture 2019, 9, 46. [CrossRef]

14. SIAP Servicio de Información Agroalimentaria y Pesquera. Available online: https://nube.siap.gob.mx/ cierreagricola (accessed on 25 September 2019).

15. AOAC. Official Methods of Analysis of Association of Official Agriculture Chemists; Association of Analytical Chemists: Washington, DC, USA, 2000.

16. Hall, G.M. Methods of Testing Protein Functionality, 1st ed.; Chapman \& Hall: London, UK, 1996.

17. Folch, J.; Lees, M.; Sloane Stanley, G. A Simple Method for the Isolation and Purification of Total Lipids from Animals Tissues. J. Biol. Chem. 1987, 55, 999-1033.

18. AOAC. Official Methods of Analysis of Association of Official Agriculture Chemists; Association of Analytical Chemists: Washington, DC, USA, 2003.

19. Ruck, J.A. Chemical Methods for Analysis of Fruit and Vegetables; Canada Department of Agriculture: Ottawa, ON, Canada, 1969.

20. Oberoi, D.P.S.; Sogi, D.S. Utilization of watermelon pulp for lycopene extraction by response surface methodology. Food Chem. 2017, 232, 316-321. [CrossRef] [PubMed]

21. Salazar-Aranda, R.; Granados-Guzmán, G.; Pérez-Meseguer, J.; González, G.; de Torres, N. Activity of Polyphenolic Compounds against Candida glabrata. Molecules 2015, 20, 17903-17912. [CrossRef]

22. Re, R.; Pellegrini, N.; Proteggente, A.; Pannala, A.; Yang, M.; Rice-Evans, C. Antioxidant activity applying an improved ABTS radical cation decolorization assay. Free Radic. Biol. Med. 1999, 26, 1231-1237. [CrossRef]

23. Kuskoski, E.M.; Asuero, A.G.; Troncoso, A.M.; Mancini-Filho, J.; Fett, R. Aplicación de diversos métodos químicos para determinar actividad antioxidante en pulpa de frutos. Food Sci. Technol. 2005, 25, 726-732. [CrossRef]

24. Burda, S.; Oleszek, W. Antioxidant and antiradical activities of flavonoids. J. Agric. Food Chem. 2001, 49, 2774-2779. [CrossRef]

25. Pérez-Meseguer, J.; Delgado-Montemayor, C.; Ortiz-Torres, T.; Salazar-Aranda, R.; Cordero-Perez, P.; de Torres, N. Antioxidant and hepatoprotective activity of Hamelia patens extracts. Pak. J. Pharm. Sci. 2015, $29,343-348$.

26. Crisan, E.V.; Sands, A. Nutrimental Value; Academic Press Inc.: New York, NY, USA, 1978.

27. Steel, R.G.D.; Torrie, J.H. Principles and Procedures of Statistics; McGraw Hill Book Co Inc.: New York, NY, USA, 1980.

28. Kabacoff, R.I. R in Action. Data Analysis and Graphics with R, 2nd ed.; Manning Publications: Shelter Island, NY, USA, 2011.

29. R Core Team. R: A Language and Environment for Statistical Computing; R Foundation for Statistical Computing: Vienna, Austria, 2019.

30. Alem, C.; Ennassir, J.; Benlyas, M.; Mbark, A.N.; Zegzouti, Y.F. Phytochemical compositions and antioxidant capacity of three date (Phoenix dactylifera L.) seeds varieties grown in the South East Morocco. J. Saudi Soc. Agric. Sci. 2017, 16, 350-357.

31. Habib, H.M.; Ibrahim, W.H. Nutritional quality evaluation of eighteen date pit varieties. Int. J. Food Sci. Nutr. 2009, 60, 99-111. [CrossRef] [PubMed]

32. Basuny, A.M.M.; AL-Marzooq, M.A. Production of Mayonnaise from Date Pit Oil. Food Nutr. Sci. 2011, 2, 938-943. [CrossRef]

33. Yousif, A.K.; Benjamin, N.D.; Kado, A. Chemical composition of four Iraqi date cultivars. Date Palm J. 1982, 1, 285-294.

34. Vinita; Punia, D. Dietary fiber and minearl composition of date palm (Phoenix dactylifera L.) Seeds. J. Pharmacogn. Phytochem. 2018, 7, 697-699. 
35. Ramchoun, M.; Alem, C.; Ghafoor, K.; Ennassir, J.; Zegzouti, Y.F. Functional composition and antioxidant activities of eight Moroccan date fruit varieties (Phoenix dactylifera L.). J. Saudi Soc. Agric. Sci. 2017, 16, 257-264.

36. Hamada, J.S.; Hashim, I.B.; Sharif, F.A. Preliminary analysis and potential uses of date pits in foods. Food Chem. 2002, 76, 135-137. [CrossRef]

(C) 2020 by the authors. Licensee MDPI, Basel, Switzerland. This article is an open access article distributed under the terms and conditions of the Creative Commons Attribution (CC BY) license (http://creativecommons.org/licenses/by/4.0/). 